\title{
Reforma kurikula pedagogicko-psychologického modulu na Pedagogické fakultě Masarykovy univerzity: Hledání kvality v ére masifikace ${ }^{1}$
}

\author{
Jana Kratochvílová, KateŘina Lojdová
}

\begin{abstract}
Abstrakt: Přispèvek mapuje reformu pedagogicko-psychologického modulu na Pedagogické fakultè Masarykovy univerzity, který je podstatnou součástí učitelských studijnich programů. Představuje východiska, postupnè se mènici strukturálni podminky a hlavni dilemata, která provázela jeho tvorbu. Na jejich základè se zaméruje na principy kvality vysokoškolské výuky a jejich evaluaci. Proces reformy kriticky zasazuje do souvislosti vysokoškolského vzdèláváni v ére masifikace. V neposledni radè text prináš́ osobni reflexe autorek podilejicich se na reformě kurikula pedagogicko-psychologického modulu.
\end{abstract}

Klićová slova: kvalita výnky, pedagogická propedeutika, reforma kurikula, vysokoškolská výuka, vzdèláváni učitelù, studenti učitelstvi.

V České republice ilustruje situaci masifikovaného vysokoškolského vzdělávání etnografická studie Dvořáčkové a kol. (2014). Převažují frontální přednášky, které nereagují na heterogenitu studentů, což také vede $\mathrm{k}$ posluchárnám, $\mathrm{v}$ nichž „student sleduje na počítači wrestling, studentka vedle něj je na facebooku a dvojice studujících se baví tak nahlas, až je okřikne studentka $\mathrm{z}$ řady před nimi“" (tamtéž, s. 38). Podobné výjevy zřejmě provázely i výuku před reformou pedagogicko-psychologického modulu na Pedagogické fakultě Masarykovy univerzity (PdF MU). Právě kvalita výuky ve velkých heterogenních skupinách se stala hlavním tématem této reformy.

Proces komplexní změny modulu pedagogicko-psychologické prŕípravy (včetně systému praxí) započal na PdF MU

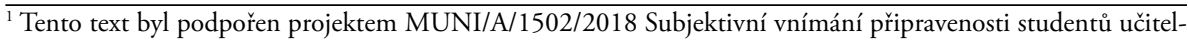
ských studijních programů navazujícího magisterského studia na svoji profesi.

${ }^{2} S$ poděkováním všem, kteří se na reformě podíleli. Zejména (abecedně): dr. Eva Janebová, prof. Tomáš Janík, dr. Josef Lukas, dr. Jan Mareš, doc. Jiř́ Němec, dr. Blanka Pravdová, dr. Zuzana Šalamounová, prof. Vlastimil Švec, doc. Kateřina Vlčková a všichni členové katedry pedagogiky.
} 
$\mathrm{v}$ roce 2012 a nový modul vešel v platnost k 1 . záŕí 2016 (viz př́loha). Máme za sebou třetí rok implementace této změny doprovázené každosemestrální evaluací, i proto jsme se rozhodli ohlédnout se zpět a reflektovat vybrané aspekty této reformy. Nabízíme čtenářům konceptuální studii opřenou o prvky evaluačních zpráv a inspirovanou designem self-study (Garbett \& Ovens, 2016), jejímž cílem je popsat a kriticky diskutovat východiska této reformy, její fáze, vybraná dilemata a námi definované principy kvality vysokoškolské výuky. Vše je zasazeno do kontextu hledání kvalitní výuky v ére masifikace vysokého školství (srov. Prudký, Pabian \& Šima, 2010).

Masifikace vysokoškolského vzdělávání zejména po Boloňském procesu (srov. Dunne \& Owen, 2013), která zpř́stupnila vysoké školy širšímu spektru populace, znamená nejen změnu kvantitativní, ale především kvalitativní. Velké množství heterogenních studentů vyžaduje proměnu výuky (srov. Lojdová, 2016a; Dvořáčková et al., 2014). Pedagogicko-psychologický modul je navíc součástí učitelské propedeutiky a týká se tak studentů např́č programy PdF MU. ${ }^{3}$

\section{ZDROJE NOVÉHO PARADIGMATU VÝUKY V RÁMCI UČITELSKÉHO VZDĚLÁVÁNí}

Naše teoretická východiska můžeme shrnout pod osobnostně-rozvojový př́- stup (Helus, Bravená \& Franclová, 2012) či př́stup zaměřený na studenta (student/ /learner-centered approach). Tento prístup se vymezuje vưči transmisivnímu modelu výuky (Tangney, 2014) a proměňuje expertní roli učitele od „držitelství obsahu“ směrem $\mathrm{k}$ facilitaci procesu učení. $\mathrm{V}$ procesu učení studenti zastávají aktivní roli a přebírají odpovědnost za tento proces (Blumberg, 2008; Kayler, 2009; Deakin et al., 2007). Celkově můžeme spolu se Svojanovským (2017) říci, že se jedná o změnu paradigmatu $\mathrm{v}$ učitelském vzdělávání, která započala na katedře pedagogiky již $s$ působením osobnosti profesora Švece (1996, 2006).

Hlavním zdrojem je pedagogický konstruktivismus, kde je student považován za hlavního aktéra profesního vývoje a (spolu)tvůrce své profesní identity. Role učitelů spočívá zejména $\mathrm{v}$ podpoře studentů $\mathrm{v}$ individualizovaném procesu „stávání se učitelem" za pomoci reflexe (srov. Korthagen, 2011; Nehyba et al., 2014a, 2014b; Svojanovský, 2017, 2018). Konstruktivistický model vzdělávání přispívá $\mathrm{k}$ proměně kultury vyučování a učení, ke které Janík (2013) přidává přívlastek produktivní (protiváha $\mathrm{k}$ receptivní) a je i výzkumně oveřen (Hattie, 2008).

Konstruktivismus zde hraje dvojroli: prostředku učitelského vzdělávání i cílové kategorie, kterou by měli budoucí učitelé ve své profesi naplňovat. Rolí vysokoškolských učitelů jako facilitátorů vzdělávání a zkušenostně-reflektivním „módem učeni“

\footnotetext{
${ }_{3}^{3}$ Jedná se tedy o předměty, do kterých vstupuje velké množství studentů (v roce 2019 je zapsáno v prvním ročníku prezenčního bakalářského studia 722 studentů).
} 
vedeme studenty $\mathrm{k}$ osvojení si konstruktivistických principů pro jejich budoucí učitelskou praxi.

$\mathrm{Na}$ základě těchto východisek nelze zcela oddělit studenta učitelství a kurikulum pedagogicko-psychologické př́pravy, nebot obojí se překrývá zejména tak, že osobnost studenta učitelství se do určité míry „stává oním kurikulem“ (srov. Conelly \& Clandidin, 1988; Lukášová-Kantorková, 2003, s. 28; Rogers, 1998).

$\mathrm{V}$ této koncepci však není kladen akcent pouze na individuální, ale i kolektivní rozměr profesionálního rozvoje (Štech, 1994, s. 313), zejména aktivní roli učitele ve společnosti (srov. Lojdová, 2016b).

$\mathrm{V}$ neposlední řadě je $\mathrm{v}$ našich východiscích prítomno akademické kurikulum charakteristické kognitivní náročností, rozvojem kritického myšlení a dovednostmi interpretace textu. Akademické kurikulum nechápeme jako protiklad osobnostně-rozvojového kurikula, nýbrž jako jeho prohlubující součást (srov. Lojdová, 2016a). Obrana akademického kurikula (napřr. Liessmann, 2008, 2015) a úvahy nad humboldtovským ideálem vzdělávání v éře masifikace (Štech, 2014; Šima \& Pabian, 2013) jsou pro nás inspirativním zdrojem v kritice osobnostně-rozvojového paradigmatu.

\section{Pedagogicko-PSyYChOlOgickÝ MOdUl Na PDF MU V PROCESU PROMĚNY}

Pedagogicko-psychologický modul (dále jen ped-psy modul) považujeme za klíčovou složku učitelského vzdělávání spolu s oborovými didaktikami (srov. Stuchlíková et al., 2015). Na rozdíl od oborových didaktik disponuje ped-psy modul přesahem $\mathrm{k}$ roli učitele obecně (nikoli jen k učiteli konkrétního předmětu) a nabízí holistický prostor pro rozvoj učitelských kompetencí a zejména učitelské identity.

Reforma kurikula ped-psy modulu se stala leitmotivem života katedry pedagogiky $\mathrm{v}$ posledních sedmi letech (započato $\mathrm{v}$ roce 2012). Změna se odehrávala $\mathrm{v}$ dynamickém mikro- i makro-institucionálním prostředí, které zachycují následující fáze.

\section{Fáze 1: Potřeba změny ped-psy modulu včetně systému praxí}

Potřeba změny stávajícího stavu vyvstala jak ze zpětných vazeb od studentů, tak i ze strany zaměstnanců katedry pedagogiky a vedení PdF MU, které kladlo důraz zejména na vytvoření nového systému učitelských praxí. Potřebu změny lze chápat jako sdílenou. $\mathrm{Na}$ začátku tohoto př́běhu stála naše potřeba dělat věci dobře, dle našeho nejlepšího vědomí a svědomí (autenticky).

\section{Fáze 2: Analýza stávajícího stavu učitelské propedeutiky}

Proces reformy kurikula započal v roce 2012 analýzou stávajícího stavu kurikula učitelské propedeutiky, vyhodnocením zpětných vazeb od studentů $\mathrm{k}$ aktuálnímu stavu, zadáním kvalitativního výzkumu kurikula v rámci bakalářské práce (Trebul'ová, 2014) a analýzou kurikula učitelské propedeutiky 
na dalších fakultách připravujících učitele. Profesní sebepojetí našich studentů a reflexe $\mathrm{v}$ př́pravě učitelů se staly tématy disertačních prací (Pravdová, 2014; Svojanovský, 2018). Na problematiku učitelských praxí byl také zaměřen specifický výzkum (Švec, Svojanovský \& Pravdová, 2016). S kolegy z Česka a Slovenska jsme sdíleli zkušenosti především s praktickou př́pravou studentů učitelství prostřednictvím konference Ucitelské praxe: soućasné poznatky a perspektivy, kterou jsme uspořádali $\mathrm{v}$ roce 2015 a ze které jsme vydali sborník (Švec, Lojdová \& Pravdová, 2016). Odnáśíme si poznatek, že neexistuje jedna správná cesta a že si musíme najít a prošlapat cestu svou.

\section{Fáze 3: Opakované diskuse v užším kruhu spolupracujících pracovišt'}

$\mathrm{Na}$ tvorbě ped-psy modulu a jeho výuce se kromě katedry pedagogiky podílela a podílejí další pracoviště PdF MU (katedra psychologie, katedra sociální pedagogiky, katedra speciální pedagogiky, Institut výzkumu školního vzdělávání, Institut výzkumu inkluzivního vzdělávání). Novou koncepci bylo třeba diskutovat a společně utvářet nejen $\mathrm{v}$ rámci uvedených pracovišt', ale i se všemi dalšími oborovými katedrami na PdF $\mathrm{MU}$, což si vyžádalo potřebu práce $\mathrm{v}$ týmech akademiků (srov. Štech, 1994). V některých diskusích jsme tvorbu kurikula ped-psy modulu přirovnávali k tvorbě Školního vzdělávacího programu a v mnoha ohledech byl pro nás tento proces stejně nový a náročný jako pro školy, které s ním začaly po kurikulární reformě (Kratochvílová, 2007).

\section{Fáze 4: Národní a fakultní kreditové rámce}

Do připravované koncepce kurikula výrazně průběžně vstupovaly požadavky MŠMT a následně i PdF MU na kreditové rámce učitelské profesní prrípravy (Rámcová koncepce př́pravného vzdělávání učitelů základních a středních škol, 2015; Rámcové požadavky na studijní programy, na jejichž základě lze získat odbornou kvalifikaci $\mathrm{k}$ výkonu regulovaných povolání, 2017; směrnice děkana). Tyto směrnice znamenaly redukci plánovaných předmětů a opětovně vyvolávaly otázku tzv. jádrového kurikula (Maňák, Janík \& Švec, 2008, s. 28), resp. obsahového jádra (Janík et al., 2013, s. 225). Bojujeme s potřebou nabídnout studentům co nejvíce $\mathrm{v}$ rámci, do kterého se musíme vejít.

\section{Fáze 5: Studenti jako spolutvůrci kurikula}

Zapojování studentů - partnerů a evaluátorů změny do designování kurikula a hodnocení jeho kvality není nikterak novou ideou (Peseta et al., 2016; Crawford, Horsley \& Parkin, 2019). Koncept „studentského partnerství" (Healey, Flint \& Harrington, 2014), „student engagement“ (Dunne \& Owen, 2013) byl v ped-psy modulu na PdF MU započat evaluacemi stávajícího stavu kurikula, avšak nastartován byl později zejména diskusemi ke koncepci kurikula se studenty ze studentské komory akademického senátu PdF MU a ze studentského spolku Otevřeno v listopadu 2015 a červnu 2016. Nejen tento 
krok předběhl v roce 2015 na MU svou dobu, nebot' oficiálně se studenti stávají členy nově zřizovaných rad studijních programů na $\mathrm{MU}$ od podzimního semestru $2019 / 2020 .^{4}$

\section{Fáze 6: Diskuse např́ič institucí}

Nově koncipované kurikulum ped-psy modulu bylo představeno členům akademické obce na podzim roku 2015. Velká účast kolegů z oborových kateder a institutů a také studentů svědčila o jejich zájmu o nové kurikulum. Otevřeně je však nutné poznamenat, že komunikace připravované změny byla boư̌livá. Zrušení některých předmětů, zavedení nových, změna garančních pracovišt', převody kreditů mezi pracovišti, ztráta moci, prostředků a prestiže, různost pohledu na změnu, hájení zájmů pracovišt (srov. Lukáš, 2016), nepochopení a nedostatek důvěry ve změnu vyvolaly mnoho negativních emocí a signalizovaly potřebu nepřetržité komunikace o inovaci naprííc všemi pracovišti. Změna narazila na institucionální hegemonické hranice fakulty - paradigmatické, teoretické, disciplinární (srov. Brooks, 2016). Změna bolí.

\section{Fáze 7: Vyhlížení standardu učitele}

Do úvah nad proměnou kurikula vstoupila snaha MŠMT schválit $\mathrm{v}$ rámci plánovaného kariérního systému pro učitele třístupňový standard učitele, který by byl postaven na profesních kompetencích učitele a jejich gradaci směrem $\mathrm{k}$ rostoucí kvalitě práce učitele. Pro PdF bylo stěžejní pojmenování kompetencí prvního kariérního stupně, jichž se mělo dosahovat zejména $\mathrm{v}$ rámci studia připravujícího $\mathrm{k}$ výkonu povolání učitele a $\mathrm{v}$ průběhu adaptačního období. Byly $\mathrm{k}$ dispozici dva návrhy (NIDV, pedagogické fakulty). Ukázalo se, že není možné najít kompromis mezi dvěma principiálně koncepčně odlišnými pojetímy kariérního systému (Janík, Spilková \& Píšová, 2014; Spilková, 2016), což vnášelo do naší práce na jedné straně nejistotu, na druhé straně nám to však poskytlo značnou svobodu.

\section{Fáze 8: Začínáme - podzimní semestr 2016}

Od záŕi 2016 jsme začali vyučovat podle nového ped-psy modulu v bakalářském i navazujícím, magisterském studiu. Šlo o období s vysokými nároky na akademické pracovníky spočívajícími nejen $\mathrm{v}$ prrípravě nových předmětů a studijních materiálů, ale i v nárocích na řízení změny. Její součástí bylo sdílení principů kvality výuky a jejich uvádění do praxe celým týmem vyučujících jednotlivých předmětů; prezentování změny vůči vnějšímu i vnitřnímu prostředí (inovace webových stránek, zřízení facebooku, tvorba informačních materiálů...), vyjednávání s dalšími pracovišti vstupujícími do ped-psy modulu. Tato fáze trvá dodnes, nebot $s$ každým akademickým rokem přibývaly nové předměty, u stávajících dochází ke změnám,

\footnotetext{
${ }^{4}$ www.em.muni.cz/komentare/11588-studenti-budou-nove-hlidat-kvalitu-studia
} 
zavádějí se opatření na základě výsledků formativní evaluace; mění se personální složení, přicházejí nové úkoly z vedení fakulty a s tím i nové výzvy.

\section{Fáze 9: Spouštíme komplexní každosemestrální evaluaci a implementujeme dílčí změny}

Od počátku implementace nového kurikula jsme si kladli otázky související $s$ jeho př́nosem. Abychom získali odpovědi na uvedené otázky, rozhodli jsme se ped-psy modul evaluovat $\mathrm{v}$ průběhu třiletého cyklu (viz Kratochvílová \& Koblihová, 2018). Jedná se o procesní a formativní autoevaluaci (Scriven, 1981, s. 53), vlastní aktivitu pracoviště (evaluace zdola), v níž z hlediska rolí splývá posuzovaný subjekt s rolí evaluátora (Hendl \& Remr, 2017, s. 292), nebot' evaluátory jsou vyučující př̀dmětů.

Sběr dat je od záŕí 2016 realizován průběžně i na konci každého semestru rozmanitými metodami a technologiemi, od tradiční papírové formy po elektronickou. Kvantitativní data nám poskytují informace o míre implementace principů kvality výuky do praxe, kvalitativní data nás vedou $\mathrm{k}$ hlubšímu přemýšlení o mnohdy neuvědomovaných složkách našich pojetí výuky.

\section{Fáze 10: Institucionální akreditace od podzimního semestru 2019}

Po dvou letech implementace inovovaného kurikula ped-psy modulu pracujeme na dalších změnách a opět zpracováváme rozsáhlé podklady pro akreditaci, tentokrát institucionální, kterou MU získala $\mathrm{v}$ roce 2018. Studenti do ped-psy modulu $\mathrm{v}$ rámci institucionální akreditace nastoupí v zárí 2019. Stávají se z nás úředníci?

\section{Dilemata Reformy}

V počáteční fázi reformy bylo nezbytně nutné vydiskutovat základní paradigmata a celkové pojetí nově nabízeného ped-psy modulu. Potýkali jsme se s podobnými problémy, s jakými se potýká výuka psychologie $\mathrm{v}$ učitelských programech: vymezení cílů kurikula (co by mělo být obsahem, $\mathrm{v}$ jakých proporcích a proč zrovna toto), metod výuky (Stuchlíková \& Mareš, 2018). Při těchto debatách vyvstala koncepční dilemata, která byla (a stále jsou) diskutována.

\section{Od konce, nebo od začátku?}

První dilema se zaměřuje na výstavbu kurikula pregraduální prŕípravy učitelů, která může schematicky směřvat od obsahu studia, na základě kterého vzniká profil absolventa, nebo od výstupu, kterým je profil absolventa, na jehož základě se odvíjí obsah studia. V podstatě se jedná o dilema akademicky versus kompetenčněl /instrumentálně vymezeného kurikula, kde $\mathrm{v}$ akademickém kurikulu je dominantní obsah vědních disciplín, zatímco v kompetenčním modelu jsou dominantní výstupy ze vzdělávání v podobě kompetencí (srov. Strouhal, 2017; Spilková, 2002; Dunne \& Owen, 2013). Naše reforma od počátku zohledňovala profil absolven- 
ta založený jak na kompetenčním modelu učitelského vzdělávání (srov. Vašutová, 2004), na modelu reflektujícího praktika (Schön, 1983) a didaktice realistického vzdělávání (Korthagen, 2011), tak na profilu vycházejícím z akademického kurikula. Akademická dimenze kurikula „vyvažuje“ některá rizika kompetenčních modelů vzdělávání, jako je „př́lilišná pragmatizace, podceňování, teorie, simplifikace edukační reality" (Strouhal, 2017, s. 63). Rizika řízení vzdělávacích systémů od výstupů, jako jsou standardy, ekonomizace a komodifikace vzdělávání (Strouhal \& Štech, 2016), částečně eliminujeme tím, že tyto výstupy vzdělávání (profil absolventa) nejsou dány zvnějšku, nýbrž vznikají přímo na fakultě, a to zdola - těmi, kdo reformu utvářejí.

Projektování kurikula vedlo obousměrně od profilu absolventa $\mathrm{k}$ obsahu studia a naopak. Kompetenční model učitelského vzdělávání hranice disciplín rozbíjí a bere nám určitou akademickou jistotu. Náš model umožnil $\mathrm{v}$ některých předmětech hranice disciplín překročit a tím nám dopřál svobodnější a flexibilnější kurikulum (např. Sebezkušenostní př́prava na profesi). Zachováním některých akademických disciplín v kurikulu pak předcházíme rizikům, jako je obsahová vyprázdněnost reflexe či podcenění teorie, které kritizují Slavík a kol. (2012) v Korthagenově konceptu. Naše kurikulum může být v protikladu $\mathrm{k}$ potřebě profesní jistoty studentů v normativním pojetí profese (srov. Spilková, 2002) - tedy návodů, jak dělat věci správně. Toto $\mathrm{v}$ našem explorativním pojetí kurikula nenabízíme už proto, že bychom takovým kurikulem prrispívali $\mathrm{k}$ de- profesionalizaci učitelství (Helus et al., 2012; Spilková, 2016). „Kuchařky po nás nechtějte", říkáme občas studentům a nabízíme jim místo toho hledání svobody v profesi s oporou o jejich výjimečnost.

\section{Disciplinarita, nebo disciplino- vaná interdisciplinarita?}

Druhé dilema reformy kurikula ped-psy modulu se týkalo disciplinarity, tedy zda stavět kurikulum po disciplínách (tradičně), nebo po tématech (mezioborově). Profil absolventa vybízel k meziooborovosti, avšak vykročení do pro nás neznámého světa, mimo známé vědní disciplíny, bylo opatrné. Podstatným faktorem interdisciplinarity v kurikulu vysoké školy jsou i podmínky financování a vykazování spojené s departmentalismem (srov. Lukáś, 2016) a potažmo i kurikulárními válkámi (Janík \& Slavík, 2018).

Hranice vědních disciplín i pracovišt garantujících tyto vědní disciplíny či předměty jsme přesto $\mathrm{v}$ některých príípadech prolomili, což nevyvolalo kurikulární války, ale zvýšenou potřebu sdílet a vyjednávat ne vždy souladné pojetí výuky např́íc různými pracovišti. Zavedli jsme tandemovou výuku vyučujících $\mathrm{z}$ různých pracovišt (napr. pedagog/psycholog a oborový didaktik v Semináŕi k učitelské praxi), což přispívá $\mathrm{k}$ narušení departmentalismu a částečné proměně kultury organizace, byt departmentalismus zůstává jedním z institucionálních limitů interdisciplinarity. Dle Lukáše (2016) je cestou ke zlepšení situace systematizovaná spolupráce mezi katedrami a sdílená vize, zaměřená na shodu nad 
profesním standardem učitele a zvyšování povědomí o tom, jak připravují studenty ostatní katedry. Na bagatelizaci významu pedagogické př́pravy upozorňuje i Lukášová-Kantorková (2003). Domníváme se, že $\mathrm{v}$ této věci je před námi stále ještě hodně práce. Naše reflexe odhaluje, že podstatou práce akademického pracovníka není jen práce samotná, ale i její komunikace do vnitřního a vnějšího prostředí fakulty. Stávají se z nás marketérí?

\section{Profesně, nebo akademicky zaměřené vzdělávání?}

V původních verzích novely vysokoškolského zákona se v roce 2013 objevovala diverzifikace vzdělávacích programů na výzkumné, akademické a profesní. Přikláníme se ke Štechovi (2014), který toto dělení vysokých škol vidí jako klišé, jež navozuje představu poměrně jasných hranic - jedni bádají a vzdělávají se výzkumem, další si osvojují poznatky vytvořené jinde a ti poslední se učí praxí zvládnout konkrétní profesi. Situace pedagogických fakult je specifická i tím, že pripravuje absolventy na státem regulovanou profesi. Profesně orientované vzdělávání je tak nasnadě. Čistě profesně orientované vzdělávání však nese riziko kladení požadavků na obsah a výstupy vzdělávání $\mathrm{z}$ trhu práce a redukci komplexního vzdělávání spíše na trénink dílčích dovedností bez hlubšího porozumění souvislostem. Profesně orientované vzdělávání lze spojit s problémy neoliberalismu a marketizací ve vzdělávání (srov. Jarkovská, 2018; Kašč́k \& Pupala, 2012; Lojdová, 2016b; Štech, 2007), která může být rizi- ková pro absolventy, profesi i vzdělávací politiku. Pro absolventy učitelských programů spočívá riziko například $\mathrm{v}$ dosažení vzdělání (výcviku), jemuž by mohla být připsána nižší symbolická hodnota oproti vzdělání absolventů akademicky orientovaných vzdělávacích programů, což by oslabilo význam profesní role učitele. Pro profesi spočívá riziko neoliberálních trendů i v tom, že do jejího vstupu by nemuselo být zapotřebí plnohodnotné vysokoškolské vzdělání. Kruh by se uzavřel delegitimizací pedagogických fakult, nebot profesně orientovaný trénink mohou poskytovat i jiné subjekty, např́íklad neziskové organizace (rychleji a levněji než univerzity). Pedagogické fakulty jsou subjekty, které mohou mít silný hlas v turbulentní vzdělávací politice a mohli by v ní mít silnější hlas i učitelé, $\mathrm{k}$ čemuž napomáhá sociální dimenze jejich profesní př́pravy. $\mathrm{Na}$ tato rizika odpovídáme akademicky pojatým vzděláváním, které však není $\mathrm{v}$ rozporu $s$ kompetenčním profilem absolventa, jehož chápeme jako kritického reflektujícího praktika v rovině individuální i sociální (srov. Strouhal, 2017).

\section{Česky, nebo anglicky?}

Dilema podoby a „míry“ internacionalizace kurikula prolínalo celým procesem tvorby ped-psy modulu a v průběhu jeho implementace rostlo jeho akcentování i ve fakultním prostředí. Internacionalizace neznamená jen podporu výměn studentů v rámci programů Erasmus a výuku v angličtině, nýbrž ji chápeme šířeji napříč kurikulem (mezinárodní diskurz $\mathrm{v}$ předmětech a využívání zahraničních 
zdrojů, práce s internacionální heterogenitou ve studijních skupinách, spolupráce se zahraničními lektory atd.). $\mathrm{V}$ ped-psy modulu je zřejmě nejvýraznějším znakem internacionalizace to, že jsou všechny povinné předměty a vybrané povinně volitelné předměty vyučovány $\mathrm{v}$ anglické jazykové mutaci. Do těchto předmětů se mohou zapsat jak studenti PdF MU, tak i studenti ze zahraničí. Internacionalizace znamená také komplexní změnu vzdělávacího paradigmatu, stává se vizí a vyžaduje změnu uvažování či mind-setu všech angažovaných osob (Janebová, 2009). Termín se stal tak často skloňovaným, že může rezonovat $s$ jeho označením za „fetiš" (Liessmann, 2008). Internacionalizace pro nás automaticky znamená práci $s$ anglickým jazykem, a tudíž i orientaci vzdělávání „anglo-americkým směrem“. Tuto orientaci můžeme kriticky reflektovat i vzhledem $\mathrm{k}$ naší společné vzdělávací historii $s$ německy mluvícími zeměni. $V$ silně internacionalizovaném kurikulu vnímáme i riziko upostranění národního kontextu, pro který budoucí učitele připravujeme.

Obeznámenost se zahraničními diskurzy a výzkumy považujeme za základní požadavek na vysokoškolského učitele. Proces socializace studenta učitelství do těchto diskurzů však vidíme jako postupný, přičemž k mezinárodnímu srovnání by mělo v některých předmětech docházet až po proniknutí do českého kontextu a terminologie. $V$ neposlední řadě je třeba v souvislosti s osobnostně-rozvojovou kon- cepcí učitelského vzdělávání zmínit význam mateřského jazyka pro myšlení.

V duchu výše uvedených teoretických východisek jsme si stanovili základní požadavky, které jsme pojmenovali jako principy kvality výuky, jejichž stručnou charakteristiku ilustrovanou daty $\mathrm{z}$ evaluace uvádíme níže.

\section{KVALITA VÝUKY PED-PSY MODULU A JEJÍ PRINCIPY}

Zájmem o kvalitu výuky ve vysokoškolském prostředí reagujeme na disproporci mezi výzkumem a výukou na vysokých školách, kde převažuje dominance výzkumná (srov. European Comission, 2013; Lojdová, 2016a). Na kvalitu výuky nahlízíme jako na proces „zlepšování modulu ped-psy př́pravy (Rais \& Münsterová, 2014, s. 11) s oporou o data, tzv. evidence-based prístup (srov. Mareš, 2018). Kromě nastíněných teoretických východisek jsme při tvorbě principů kvality výuky vycházeli i ze vzdělávacích biografí členů katedry pedagogiky (univerzitní vzdělávání v Česku a v zahraničí, absolvované výcviky, zkušenostní a reflektivní kurzy atd.) a z požadavků na kvalitu výuky v mezinárodním i českém kontextu (Delaney et al., 2010; Hativa, 2013; Wright et al., 2014; Standards, 2015; Crawford et al., 2019, s. 166-177; Kaplánek \& Kočerová, 2011). Pro ilustraci reflexe principů kvality výuky studenty přikládáme vybrané studentské výroky z evaluace jednotlivých předmětů. ${ }^{5}$

\footnotetext{
${ }^{5}$ Evaluaci kurikula ped-psy modulu a její metodologii se budeme vzhledem k rozsahu textu věnovat $\mathrm{v}$ jiném publikačním výstupu. Zde jsou data uvedena pouze ilustrativně.
} 


\section{Princip vytváření bezpečného prostředí ve výuce}

Student většinou nepostupuje učitelskou propedeutikou v jedné stabilní studijní skupině, ale v každém semestru a v každém předmětu je členem jiné studijní skupiny. Pro vyučující to znamená pracovat každý semestr ve svých předmětech $s$ nově utvořenou rozmanitou studijní skupinou. To klade základní požadavek na zabezpečení respektujícího bezpečného prostředí ve výuce, které podporuje atmosféru pracovní pohody, diskuse, spolupráce, sdílení a učení studentů (srov. Brown \& Edmunds, 2017; Janštová \& Slezáčková, 2018). Podporujeme kulturu učení založenou na respektu, což znamená nejen druhého oceňovat a uznat jeho odlišnost, ale být otevřený i jeho působení na nás. Prožitky studentů z předmětů ped-psy modulu dokládáme výroky studentů z evaluace: „Atmosféra byla opravdu príjemná, jednak díky super kolektivu a také prístupu vyučujici" (Sociálně-patologické jevy v životě žáků ZŠ a studentů SS̆, JS 20186).

Naplnění potřeby úcty, oslovování jménem, poznání spolužáků, vykomunikování pravidel jednání, vymezení výstupů, diferenciace úkolů, sladění očekávání na samém počátku, čas věnovaný seznámení, to vše ovlivňuje atmosféru ve výuce a pokládá základy bezpečí ve skupině. Jsme přesvědčeni, že zkušenost se vzděláváním $\mathrm{v}$ bezpečném prostředí může vést $\mathrm{k}$ jeho transferu do praxe studentů - budoucích učitelů.

\section{Princip zaměření na dosahování stanoveného cíle a na smysluplnou výuku}

„Cíle slouží jako kotva, která ovlivňuje veškeré jednání, bohužel jsou občas formulovány takovým způsobem, že se odchylují od svého potenciálu účinně ovlivňovat učení žáka" (Ford, 1992, s. 43). Koncepce cílů výuky je klíčová i proto, že v návaznosti na obsah do značné míry rozhoduje o tom, zda ve výuce bude převažovat důraz na ryze akademické znalosti, nebo zda bude brán ohled na jejich vztah k praxi (Nohavová \& Sokolová, 2018). Přitom stanovení a sdílení jasného učebního cíle a kritérií úspěchu představuje klíčovou strategii pro zlepšení výsledků studentů ve vysokoškolské př́pravě (Hattie, 2008, s. 130). $\mathrm{K}$ efektivnímu učení studentů přispívá, vnímají-li učební aktivity rovněž jako smysluplné a znají-li, co a v jaké kvalitě se od nich očekává. Hledání a objasňování cílů učení, smyslu učení se teoretickým konceptům a možnostem jejich propojení $\mathrm{s}$ praxí přispívá $\mathrm{k}$ integritě výuky (Janík, 2013, s. 13). Studenty je tento prístup oceňován: „Libil se mi seminár jako takový. Vyucuujici byla vždy pripravená, jeji výnka byla velmi nabitá, ale často se nás ptala na naše postrehy a názory. Libilo se mi, že nám na začátku výnky jasnè sdèlila, co je obsahem kurzu, $k$ čemu nám to bude dobré, a taky všechny své cíle dodržela" (Školní pedagogika, PS 2017).

\section{Princip rozmanitosti $v$ používání výukových metod a forem}

Tento princip reaguje na rozmanité spektrum studentů, kteři předměty ped-psy

${ }^{6} \mathrm{JS}=$ jarní semestr, PS = podzimní semestr. 
modulu absolvují a kteří mají také rozdílné důvody ke studiu. $\mathrm{V}$ prýpadě budoucích učitelů druhého stupně základních škol je to podle zahraničních výzkumů převážně zájem o vybraný studijní obor a sdílení odborných znalostí (Younger et al., 2004). I když studenti chtějí být dobrými učiteli, předměty pedagogické propedeutiky stojí mnohdy „ve stínu“ předmětů oborových. $\mathrm{O}$ to více je třeba promýšlet, jak zpřístupnit obsahovou dimenzi kurikula předmětů, které mají studentům pomoci při budování jejich pojetí výuky a profesní identity. Narušit tradici akademicky a tradičně zaměřené profesní přípravy není jednoduché, jak dokumentujeme na následujícím př́kladu: "Kontroverzni a netradični techniky uvažováni, preméśleni, práce s myšlenim mi vyhovovaly. Některým spolužákuim to bylo nepríjemné, nechtěli se do toho moc zapojovat, ale já to brala jako možnost seznámeni se sněcím novým. Proto radím nenechat se od uživáni netradičnich forem výuky odradit. Ne každému to sedne, ale ta zkuśenost ( $i$ když negativni) je $k$ nezaplaceni! :-) “ (Sebezkušenostní př́íprava na profesi, PS 2018).

Využívané výukové metody vycházejí zejména $\mathrm{z}$ prrístupu aktivizujícího učení žáků (active learning viz Jones, 2014; Weltman \& Whiteside, 2010; Barkley \& Major, 2018), v němž díky spolupráci, kooperaci a řešení problémů v menších skupinách dochází $\mathrm{k}$ neustálé interakci mezi subjektem vzdělávání (studentem/studenty), obsahem i vyučujícím v rámci společenství trrídy/skupiny. $\mathrm{Na}$ jejich př́nos poukazuje řada výzkumů: zvyšují zájem a angažovanost studentů ve výuce, rozvíjejí kritické myšlení, zvyšují kognitivní nároč- nost výuky i spokojenost $s$ výukou (Mello \& Less, 2013; Jones, 2014), podporují dosahování učebních výstupů (Barkley, Major \& Cross, 2014; Davidson \& Major, 2014).

Koncentrace na aktivizující učení studenta, které podpoporuje jeho autonomii, je pro nás štítem deprofesionalizace učitelské př́ipravy (viz Švecová \& Vašutová, 1997, s. 121). Z reakcí studentů na hodnocení tohoto principu výuky vybíráme: "Líbil se mi celkový kontext výuky a názorné ukázky, videa, práce ve skupinách a vytvoření bezpečného prostredi" (Pedagogicko-psychologická diagnostika, PS 2018).

\section{Princip provázanosti teorie a praxe}

Vztah teorie a praxe $\mathrm{v}$ profesní př́íprave učitelů $\mathrm{v}$ sobě nese napětí (srov. Maňák, 2011; Kota, 2012), které se snažíme $\mathrm{v}$ reformě mírnit. Jeden $\mathrm{z}$ úhlů pohledu na propojení teorie a praxe je vnořen do koncepce kurikula jako vzájemně provázaného kontinua předmětů orientovaných na obsah disciplíny (teorie) a předmětů orientovaných na zkušenost studenta (praxe) (viz obr. 1).

Propojení teorie a praxe však nachází své místo i v teoretických předmětech ped-psy modulu. Teoretické koncepty jsou propojovány s praktickými př́klady, zkušenostmi vyučujících i studentů, jsou diskutovány a často ústí v závěrečný úkol, $\mathrm{v}$ němž mohou studenti své znalosti a dovednosti aplikovat a následně reflektovat: „Prínosem pro mě bylo praktické ukončení predmètu. Teoretické znalosti jsme využili 


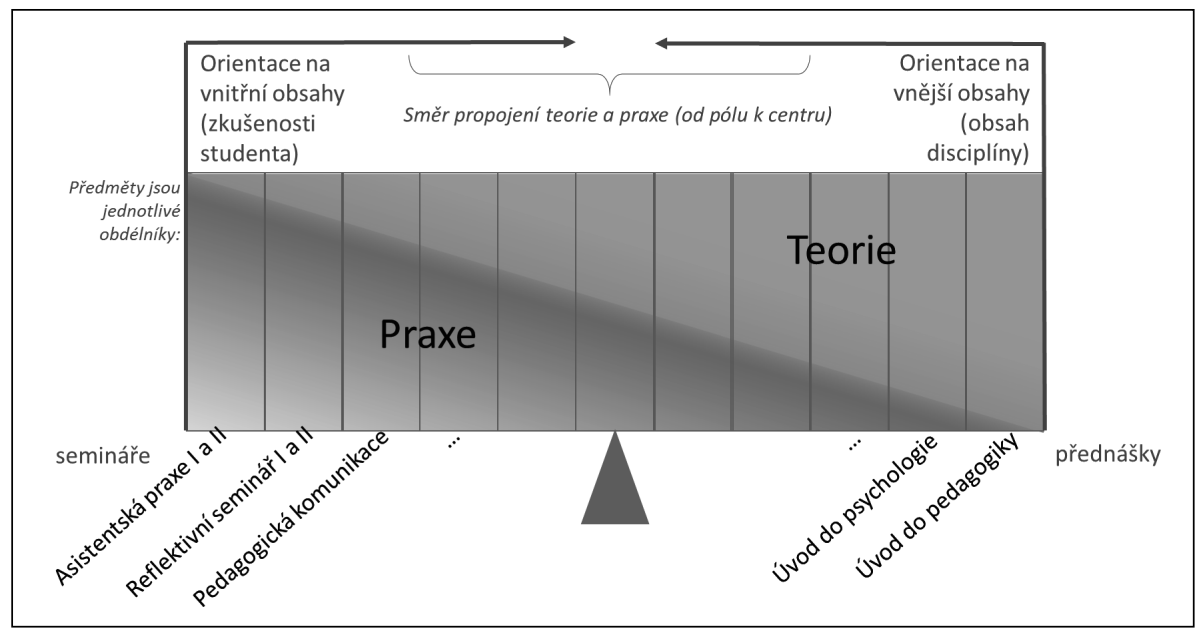

Obr. 1. Propojení teorie a praxe (upraveno dle Janík, 2005)

$v$ praktickém úkolu" (Základy pedagogicko-psychologické diagnostiky, JS 2018).

$\mathrm{V}$ souladu s konstruktivistickým modelem vzdělávání propojujeme teorii a praxi přes zkušenost studentů, k čemuž se nabízí zejména reflektivní semináře navázané na praxi. Zde se nabízí prostor rámovat zkušenosti studentů teoriemi, které nevycházejí z kurikula plánovaného, nýbrž $\mathrm{z}$ kurikula realizovaného a zejména $\mathrm{z}$ aktuálních potřeb studentů. Podle Svojanovského (2017, s. 131) však úspěšná podpora reflexe praxe vyžaduje alternativní paradigma výuky, kulturu reflektivní praxe, která se nevytváří pouze $\mathrm{v}$ jednom předmětu, jenž je cíleně na reflexi praxe zaměřen, ale její úspěšné ustavení vyžaduje proměnu jednání a přesvědčení také v dalších předmětech, tedy na úrovni programu učitelského vzdělávání. Tomuto procesu jdeme naproti nejen týmovou výukou v Semi- nářích $\mathrm{k}$ učitelské reflexi, na nichž participuje oborový didaktik a pedagog nebo psycholog, ale i podporou reflexe v dalších předmětech. Velký přínos spatřujeme také v rozšiřování okruhu odborníků - provázejících učitelů, kteří se zapojují do skupinové reflexe: "Nejvice mi vyhovovalo, když jsme méli prostor podélit se sostatnimi o tom, co právè résime na praxi, pokud se vyskytly nějaké problémy. Prínosný pro mé byl nejen pobled ucitele, ale právě $i$ ostatnich spolužákü, kterí se $k$ danému tématu vyjadrovali" (Seminář k učitelské praxi, PS 2017).

\section{Princip vedení studentů k odpovědnosti za své vlastní učení}

Vyučování a učení na vysoké škole je proces se zodpovědností na obou stranách - studenta i učitele, oba ovlivňují výsledek 
učení. Podle Rogerse (in Bertrand, 1998) je učení usnadněno, nese-li student v procesu učení svou část odpovědnosti. Kromě obecného př́stupu podporuje odvědnost studentů možnost volby, která prochází např́č kurikulem: např. systém povinně-volitelných a volitelných seminářủ $\mathrm{k}$ individuálnímu profesnímu rozvoji, dílčích úkolů na seminárích, způsobů jejich zpracování, prezentování, diferenciace portfoliových úkolů a celková koncepce studentského portfolia (využívaného při státní závěrečné zkoušce) přispívá ke „zplnomocnění studentü“ (student empowerment). Hlas studentů učitelství ve vzdělávání přispívá k větší odpovědnosti studentů za učení (ownership) a může dokonce vzbudit vášeň pro učení (Bryer \& Seigler, 2012): „Oceñuji celkový zpìsob výuky v tom, že pokud jsme néco dèlat nechtéli, nemuseli jsme, nikdo nás do ničeho netlačil a neprikazoval nám, co musime dělat" (Sebezkušenostní př́prava na profesi, PS 2017).

Princip vedení studentů $\mathrm{k}$ odpovědnosti za své vlastní učení naplňujeme např́ic kurikulem i u státní závěrečné zkoušky také studentským portfoliem (např. Vašutová, 2002; Svatoš, 2006; Spilková a Vašutová, 2008; Píšová, 2007; Lukášová, Svatoš \& Majerčíková, 2014). Studentské portfolio je aktivním prvkem $\mathrm{v}$ procesu stávání se učitelem. Předměty ped-psy modulu obsahují tzv. portfoliové úkoly, které tvoří hlavní součást studentského portfolia a které mimo jiné vedou k propojování teoretických znalostí s jejich aplikací do pedagogické reality ve škole. Takto pojímané portfolio chápeme jako individualizovaný portrét studenta mapující jeho vývoj.

\section{Princip výuky založené na výzkumu, reflexi a zpětné vazbě}

Prostřednictvím investigativních přístupů se u studentů rozvíjí kritické myšlení a ochota prozkoumávat vlastní činnost. Tímto principem tedy také naplňujeme „zplnomocnění" studentů ve výuce a prohloubení jejich profesionalizace. Stěžejní triádou investigativních prrístupů je výzkum, reflexe, zpětná vazba (Lojdová, 2016a; Schön, 1983; Korthagen, 2011; Barkley \& Major, 2018). Užitečnou zpětnou vazbu chápeme jako základní princip formativního hodnocení (Starý, 2007) a formulujeme tedy pravidlo „zpětné vazby ke každému úkolu“. Studenti zpětnou vazbu od vyučujících oceňují a její průběžnost jim napomáhá v plnění úkolů: „Celkové pojetí semináre se mi velmi líbilo, vždycky jsme $k$ úkolìm dostali zpètnou vazbu. Učitelka byla na hodiny výborně pripravena, vždy nám sdèlila jasnou strukturu hodiny" (Školní pedagogika, PS 2017).

\section{Princip sdílení zkušeností $\mathrm{z}$ výuky a společná zodpovědnost za její kvalitu}

Nelze zpochybnit, že učitelé jsou vůdčími aktéry výuky (srov. Helus, 2012). $\mathrm{V}$ našem př́ipadě je nezbytně nutné dodat, že tato individuální odpovědnost se v masifikovaném univerzitním vzdělávání pojí se zodpovědností kolektivní. Za kvalitu výuky daného předmětu nenese zodpovědnost pouze jednotlivec, ale celý tým vyučujících, který je řízen garantem předmětu. 
Garant předmětu zabezpečuje pravidelná setkávání všech vyučujících $\mathrm{k}$ obsahové i metodické dimenzi kurikula, organizuje pravidelnou evaluaci na konci semestru, její vyhodnocení i uvádění nastavených opatření do praxe, komunikuje výsledky evaluce na pracovišti. To, že učitelé vědí, co je obsahem jiných předmětů, se pak promítá i v evaluaci: „Nejlepši byl prístup vyučujicí, vše nám ochotnè vysvétlila a je vidèt, že ví o tom, co se učime" (Výzkum v pedagogické praxi, PS 2018).

\section{OHLÉDNuTí ZA REFORMOU}

\section{ANEB CO JSME SE NAUČILI?}

Celou reformu chápeme jako proces organizačního i individuálního učení. Katedra pedagogiky se stala učící se pospolitostí se sdílenými hodnotami, kolegiálními vztahy, s kulturou podporující učení sebe i druhých, se zájmem o reflexi i evaluaci (Pol, 2007), svébytnou komunitou praxe (Wenger, 1999). To neznamená, že nejsou sdíleny a diskutovány rozdílné názory. Jejich komunikace však probíhá v otevřeném a respektujícím prostředí $s$ cílem dojít k závěrům, které jsou v souladu se sdílenými hodnotami a koncepčními záměry.

Změna ped-psy modulu je dlouhodobou a komplexní záležitostí. Přestože je tato složka profesní prípravy zabezpečována především katedrou pedagogiky a psychologie, je neoddělitelnou součástí oborové a didaktické profesní př́pravy. Postoje, jednání, komunikace vizí, cílů a výukové procesy vzdělavatelů všech studentů se vzájemně mísí ve směs, jejíz konzistence působí na vývoj profesní identity studentů.
Profesní prríprava studentů učitelství přesahuje rámec katedry pedagogiky, prostupuje kulturami mnoha pracovišt', se kterými hledáme cesty vzájemného porozumění a to, co máme společné, nebo $\mathrm{v}$ čem se vzájemně doplňujeme. Hlavním důvodem je snaha co nejlépe připravit absolventa, kterého naprríč pracovišti „sdílíme“. Jinými slovy, ještě je toho mnoho před námi.

Jana Kratochvílová: Neměla jsem tolik štěstí, abych stála u zrodu myšlenek vybízejících $\mathrm{k}$ reformě ped-psy složky profesní přípravy. Moje profesní dráha se ubírala jinou cestou. I přesto se stalo, že jsem se od ledna roku 2016 stala součástí katedry pedagogiky a vstoupila do toku událostí spjatých s finalizací ped-psy modulu předkládáného $\mathrm{k}$ akreditaci. Mým úkolem garanta bylo ve spolupráci se všemi, kdo se na tvorbě plánovaného kurikula podíleli, „vdechnout mu život“. Vstoupila jsem do neznámé „řeky“ nových kolegů, jejich zvyklostí, vztahů, představ, společných prožitků, které jsem $s$ nimi dosud nesdílela. Vlastně jsme všichni prožívali změny dvě: kurikulární a personální. Díky společné vizi, hodnotám, vynaloženému úsilí a přesvědčení o smysluplnosti našeho jednání jsme se společně rozvíjeli. Katedra pedagogiky se stala pracovištěm, kde se individuální spojilo se společným a vyústilo synergicky ve vztahy, které podporují a vytvářejí podmínky potřebné pro posun od "já" k „my“ (srov. Pol, 2007). Tuto kulturu sdílených hodnot a kolegiálních vztahů, vzájemné podpory, ochoty, pochopení a „podržení se“ nelze prìimout jako samozřejmost, je to něco vzácného, o co se 
musí pečovat a rozvíjet to. Je to něco, co je součástí těch, kteří byli u tohoto procesu a kteř́ by měli toto poselství vtisknout těm, kteří teprve přijdou. Po třech letech implementace inovovaného kurikula se nacházíme ve fázi, která přináší první „vítězstvi", prožitky spokojenosti, radosti z vynaloženého úsilí, ale $\mathrm{i}$ únavy a obav do budoucna. Stojíme na tenkém ledě, který může mít mnoho prasklin časem se rozrůstajících $\mathrm{v}$ hustou sít: personální obměny na pracovišti; časové vytížení a náročnost, kterou uchování nastavených hodnot vyžaduje; touha a potřeba orientovat se nyní více na výzkumnou a tvůrčí činnost; změna vyučujících na spolupracujících katedrách; vstup externích pracovníků, kteří tyto hodnoty nesdílejí; přesycenost úkoly „nadkatedrálnho“ charakteru (budování systému kvalitních fakultních škol, administrace a evaluace praxí, rozvojové projekty...). To vše může svádět $\mathrm{k}$ cestě zpět a vzít nám to nehmatatelné, hodnotné a křehké, co je naší součástí a na čem můžeme stavět. Čeká nás etapa udržení změny, která bývá přirovnávána ke spirále - není statická, nedá se předpokládat, že bude jednoduchá, a určitě bude další výzvou. Mým přáním je, aby zastavení na této cestě byla krátkodobá a vedla k promyšleným dalším krokům, které budou vycházet z již ušlé cesty, budou chtěny, podporovány a přispějí dlouhodobě k profesionalizaci učitelství.

Je čas stabilizovat nastavené procesy kvality ve výuce, udržet fungující úroveň spolupráce s fakultními školami a zařízení$\mathrm{mi}$ a těšit se $\mathrm{z}$ těchto výsledků. Je čas věnovat energii dalším oblastem.
Kateřina Lojdová: Proces reformy kurikula ped-psy modulu je pro mě spojen $s$ celým působením na katedře pedagogiky PdF MU. Znamenal pro mě chvíle nadšení i beznaděje, chvíle tvůrčí radosti z proměny podmínek učitelského vzdělávání i okamžiky vyčerpání. Při tvorbě tohoto textu jsem se vrátila $\mathrm{k}$ materiálům $\mathrm{k}$ reformě kurikula od roku 2012. Jedná se o „stoh“ dokumentů, který by sám o sobě poskytl bohatá data pro analýzu reformy kurikula. Vidím, kolik osob je podepsáno pod hodinami různých schůzek, koncepčními dokumenty, vizualizacemi koncepce a dílčími úkoly. Vnímám obrovské úsilí mnoha lidí vložené do této reformy, ale i úsilí nezbytné pro každodenní realizaci výuky. Není naše idea kvality v masifikovaném vzdělávání utopická? Jistou cenu masifikace platíme např. testováním, které zůstalo součástí některých př̀edmětů, byt jeho místo v konstruktivistickém kurikulu je diskutabilní (srov. Windschitl, 2002). Je zamýšlená excelence udržitelná v současných podmínkách? Otázka udržitelnosti pro mě nyní předběhla otázku excelence. Na změnu strukturálních podmínek jsme si již zvykli (viz fáze reformy), jádrem reformy jsou však lidé. Dynamika a diverzita týmu vyučujících je jistě žádoucí. Pravidelná obměna týmu vyučujících však přináší velké nároky na garanty předmětů a sdílení kritérií kvalitní výuky napříč jednotlivými semináři. $\mathrm{V}$ tomto úhlu pohledu by mohli přispět $\mathrm{k}$ udržitelnosti reformy inbreedovaní kolegové - doktorandi (srov. Tůma \& Knecht, 2019). Avšak získávání doktorandů je podmíněno pěstováním výzkumu. Přes 
masy studentů $\mathrm{v}$ bakalářském studiu jako by nezbýval čas na naše budoucí kolegy doktorandy. Stále častěji si také uvědomuji, co nás tato reforma „stála“ ve vztahu $\mathrm{k}$ výzkumu, který byl z mého úhlu pohledu přesunut „na druhou kolej“, byt' katedra pedagogiky řešila $v$ posledních letech čtyři projekty GA ČR. Výzkum přitom chápeme jako jeden z principů kvalitní výuky (srov. Lojdová, 2016a). Pro mě osobně je výzkum součástí profesní identity, kterou lze pojmenovat jako univerzální, tzn. rozkročenou mezi výzkumem a výukou (Šed’ová et al., 2016).

\section{LITERATURA}

Barkley, E. F., \& Major, C. H. (2018). Interactive lecturing: A handbook for college faculty. San Francisco, CA: Jossey-Bass.

Barkley, E. F., Major, C. H., \& Cross, K. P. (2014). Collaborative learning techniques: A resource for colledge fakulty ( $2^{\text {nd }}$ ed.). San Francisco, CA: Jossey-Bass.

Bertrand, Z. (1998). Soudobé teorie vzdělávání. Praha: Portál.

Blumberg, P. (2008). Developing learner-centred teaching: A practical guide for faculty. San Francisco: Jossey Boss.

Brooks, C. F. (2016). Role, power, ritual, and resistance: A critical discourse analysis of college classroom talk. Western Journal of Communication, 80(3), 348-369.

Brown, G., \& Edmunds, S. (2017). Effective teaching? In E. Roger \& E. Hogard (Eds.), Handbook of quality assurance for university teaching. London: Routledge.

Bryer, T. A., \& Seigler, D. (2012). Theoretical and instrumental rationales of student empowerment through social and web-based technologies. Journal of Public Affairs Education, 18(3), 429-448.

Connelly, F., \& Clandinin, D. (1988). Teachers as curriculum planners: Narratives of experience. Toronto: OISE Press.

Crawford, C., Horsley, R., \& Parkin, E. (2019). How can student engage in assuring the quality of university teaching? In E. Roger \& E. Hogard (Eds.), Handbook of quality assurance for university teaching (s. 166-177). London: Routledge.

Davidson, N., \& Major, C. H. (2014). Boundary crossing: Cooperative learning, collaborative learning, and problem-based learning. Journal on Excellence in Colledge Teaching, 25(3-4), 7-55.

Deakin, C. R., McCombs, B., Haddon, A., Broadfoot, P., \& Tew, M. (2007). The ecology of learning: Factors contributing to learner-centerd classroom cultures. Research Papers in Education, 22(3), 267-307.

Delaney, J., Johnson, A., Johnson, T., \& Treslan, D. (2010). Students' perceptions of effective teaching in higher education. The $26^{\text {th }}$ Annual Conference on Distance Teaching and Learning. Dostupné z www.uwex.edu

Dunne, E., \& Owen, D. (Eds.). (2013). Student engagement handbook: Practice in higher education. London: Emerald. 
Dvořácková, J., Pabian, P., Smith, S., Stöckelová, T., Šima, K., \& Virtová, T. (2014). Politika a každodennost na českých vysokj́ch školách: Etnografické pobledy na vzdèláváni a výzkum. Praha: SLON.

European Commission (2013). High Level Group on the Modernisation of Higher Education: Report to the European commission on improving the quality of Teaching and learning in europe's higher education institutions. Luxembourg: EU.

Ford, M. E. (1992). Motivating humans: Goals, emotions, and personal agency beliefs. London: SAGE.

Garbett, D., \& Ovens, A. (Eds.). (2016). Enacting self-study as methodology for professional inquiry. Self-Study of Teacher Education Practices (S-STEP).

Hativa, N. (2013). Student ratings of instruction: Recognizing effective teaching. Oron Publications.

Hattie, J. (2008). Visible learning: A synthesis of over 800 meta-analyses relating to achievement. Abingdon: Taylor \& Francis.

Healey, M., Flint, A., \& Harrington, K. (2014). Engagement through partnership: Students as partners in leaning and teaching in higher education. York: HEA.

Helus, Z., Bravená, N, \& Franclová, M. (2012). Perspektivy učitelství. Praha: Pedagogická fakulta UK.

Hendl, J., \& Remr, J. (2017). Metody výzkumu a evaluace. Praha: Portál.

Janebová, E. (2009). Vedení internacionalizace vysokých škol. Studia paedagogica, 14(2), $107-130$.

Janík, T. (2005). Znalost jako kličová kompetence učitelského vzdèlávání. Brno: Paido.

Janík, T. (2013). Od reformy kurikula k produktivní kultuře vyučování a učení. Pedagogická orientace, 23(5), 634-663.

Janík, T., \& Slavík, J. (2018). Kurikulárni války, departmentalismus a transdidaktika. Plenární přednáška na XXVI. ročníku konference České asociace pedagogického výzkumu. Univerzita Tomáše Bati ve Zlíně.

Janík, T., et al. (2013). Kvalita (ve) vzděláváni: Obsahově zaměrený prístup ke zkoumáni a zlepšování výuky. Brno: Masarykova univerzita.

Janík, T., Spilková, V., \& Píšová, M. (2014). Standard a kariérní systém učitele: Problémy předložené koncepce v širších souvislostech. Pedagogická orientace, 24(2), 259-274.

Janštová, E., \& Slezáčková, A. (2018). Pozitivní edukace - inspirace zlepšení kvality vzdělávání. Lifelong Learning - celoživotni vzdèlávání, 8(3), 7-24.

Jarkovská, L. (2018). Ohrožují soukromé školy rovný př́stup ke vzdělávání v České republice? Sociálni pedagogika, 6(1), 47-57.

Jones, J. M. (2014). Discussion group effectiveness is related to critical thinking through interest and engagement. Psychology Learning and Teaching, 13(1), 12-24.

Kaplánek, M., \& Kočerová, M. (2011). Participace - nejlepší způsob výchovy k demokracii. E-pedagogium, 1, 18-37. 
Kašćák, O., \& Pupala, B. (2012). Škola zlatých golierov: vzdelávanie vére neoliberalizmu. Praha: SLON. Kayler, M. A. (2009). Teacher development and learner-centered theory. Teacher Development, 13(1), 57-69.

Korthagen, F. A. J. (2011). Jak spojit praxi s teorii: Didaktika realistického vzdèláváni učitelů. Brno: Paido.

Kota, J. (2012). Traktát o vybraných problémech teorie a praxe v oblasti pedagogických věd. Pedagogická orientace, 22(3), 336-352.

Kratochvílová, J. (2007). Učitelé škol v nové roli „tvưrcü“ kurikula. Orbis scholae, 2(1), 101-110.

Kratochvílová, J., \& Koblihová, H. (2018). Formativní evaluace pedagogicko-psychologické složky profesní př́ípravy. In J. Malach, D. Vicherková (Eds.), Otázky evaluace výuky na vysokých školách (s. 49-62). Ostravská univerzita.

Liessmann, K. P. (2008). Teorie nevzdělanosti: Omyly společnosti védění. Praha: Academia.

Liessmann, K. P. (2015). Hodina duchü: Praxe nevzdělanosti. Praha: Academia.

Lojdová, K. (2016a). Sňatek z rozumu? Výzkum a výuka v pregraduální přípravě učitelů na pŕíkladu kvalitativního výzkumu. Pedagogická orientace, 26(1), 51-75.

Lojdová, K. (2016b). The end of academic freedom in the era of neoliberalism? Pedagogická orientace, 26(4), 605-630.

Lukáś, R. (2016). Institucionální bariéry zlepšování př́ípravy učitelů: Departmentalismus na pedagogické fakultè. Aula, 24(2), 21-38.

Lukášová, H., Svatoš, T., \& Majerč́ková, J. (2014). Studentské portfolio jako výzkumný prostředek poznáni cesty $k$ učitelstvi. Príspèvek $k$ autoregulaci profesního učeni a seberozvoje. Univerzita Tomáše Bati ve Zlíně.

Lukášová-Kantorková, H. (2003). Ucitelská profese v primárním vzdèláváni a pedagogická príprava učiteli̊. Ostrava: Pedagogická fakulta OU.

Maňák, J. (2011). K problému teorie a praxe v pedagogice. Pedagogická orientace, 21(3), 257-271.

Maňák, J., Janík, T., \& Švec, V. (2008) Kurikulum v současné škole. Brno: Paido.

Mareš, J. (2018). Př́ílady dobré praxe v pedagogice. Pedagogika, 68(4), 378-412.

Mello, D., \& Less, C. A. (2013). Effectiveness of active learning in the arts and science. Humanities Department Faculty Publications and Research, Paper 45.

Nehyba, J., Koláŕ, J., Dubec, M., et al. (2014a). Reflexe mezi lavicemi a katedrou. Brno: Masarykova univerzita.

Nehyba, J., Lazarová, B., Kolb, D. A., et al. (2014b). Reflexe v procesu učeni: Desetkrát stejně a prece jinak... Brno: MuniPress.

Nohavová, A., \& Sokolová, L. (2018). Obsah a cíl výuky psychologie z pohledu studentů učitelských oborů. Pedagogika, 68(4), 349-366.

Peseta, T., Bell, A., Clifford, A., et al. (2016). Students as ambassadors and researchers of assessment renewal: Puzzling over the practices of university and academic life. International Journal for Academic Development, 21(1), 54-66. 
Píšová, M. (Ed.). (2007). Portfolio v profesni prípravě učitele. Univerzita Pardubice.

Pol, M. (2007). Škola v proménách. Brno: Masarykova univerzita.

Pravdová, B. (2014). Já jako učitel: Profesni sebepojetí studenta učitelství. Brno: Masarykova univerzita.

Prudký, L., Pabian, P., \& Šima, K. (2010). České vysoké školstvi: Na cestě od elitniho k univerzálnímu vzdéláváni 1989-2009. Praha: Grada.

Rais, K., \& Münsterová, E. (2014). Metodika IPN Kvalita. Praha: MŠMT.

Rámcová koncepce prípravného vzdéláváni učitelù základnich a střednich škol (2015). Praha: MŠMT.

Rámcové požadavky na studijni programy, na jejichž základè lze ziskat odbornou kvalifikaci k výkonu regulovaných povoláni (2017). Praha: MŠMT.

Rogers, C. (1998). Zpisob bytí. Kličová témata humanistické psychologie z pohledu jejího zakladatele. Praha: Portál.

Scriven, M. (1981). Evaluation thesaurus. EdgePress.

Schön, D. (1983). The reflective practitioner. London: Temple Smith.

Slavík, J., Janík, T., Najvar, P., \& Píšová, M. (2012). Mezi praxí a teorií v učitelském vzdělávání: $\mathrm{Na}$ okraj českého překladu knihy F. A. J. Korthagena et al. Pedagogická orientace, 22(3), 367-386.

Spilková, V. (2002). Klíčové koncepty v současných proměnách učitelského vzdělávání - reflexe, sebereflexe, konstruktivistické př́istupy. In E. Walterová (Ed.), Výzkum školy a učitele. Sbornik z 10. výročni konference ČAPV s mezinárodni účastí. Praha: Pedagogická fakulta UK.

Spilková, V. (2016). Př́stupy české vzdělávací politiky po roce 1989: Deprofesionalizace učitelství a učitelského vzdělávání? Pedagogika, 66(4), 368-385.

Spilková, V. (2007). Učitelská profese v měnících se požadavcích na vzdělávání. Pedagogika, 57(4), 338-348.

Spilková, V., \& Vašutová, J. (Eds.). (2008). Učitelská profese v měnicich se požadavcích na vzděláváni. Praha: Pedagogická fakulta UK.

Standards and Guidelines for Quality Assurance in the European Higher Education Area (ESG). (2015). Brusel.

Starý, K. (2007). Formativní hodnocení ve školní výuce. In D. Greger \& V. Ježková (Eds.), Školni vzděláváni. Zahranični trendy a inspirace (s. 221-242). Praha: Karolinum.

Stöckelová, K. Šima \& T. Virtová, Politika a každodennost na českých vysokých školách: Etnografické pohledy na vzdèláváni a výzkum. Praha: SLON.

Strouhal, M. (Ed.). (2017). Učit se být učitelem: K vybraným problémům učitelského vzdèlávání. Praha: Karolinum.

Strouhal, M., \& Štech, S. (2016). Vzdèlání a dnešek: Pedagogické, filosofické, historické a sociální perspektivy. Praha: Karolinum.

Stuchlíková, I., \& Mareš, J. (2018). Potíž s výukou psychologie v učitelských programech. Pedagogika, 68(4), 341-347. 
Stuchlíková, I., Janík, T., Beneš, Z., Bílek, M., Brücknerová, K., Černochová, M. et al. (2015). Oborové didaktiky: Vývoj - stav - perspektivy. Brno: Masarykova univerzita.

Svatoš, T. (2006). Studentské portfolio v učitelském studiu jako zdroj poznání postojů začínajících studentů učitelství. Pedagogika, 56(1), 45-57.

Svojanovský, P. (2017). Supporting student teachers' reflection as a paradigm shift process. Teaching and Teacher Education, 66, 338-348.

Svojanovský, P. (2018). Podpora reflexe praxe v učitelském vzděláváni (Disertační práce). Brno: Masarykova univerzita.

Šed'ová, K., Švaříček, R., Sedláčková, J., et al. (2016). Pojetí výuky a profesní identita začínajících vysokoškolských učitelù. Studia paedagogica, 21(1), 9-34.

Šima, K., \& Pabian, P. (2013). Ztracený Humboldtiov ráj: Ideologie jednoty výzkumu a výnky ve vysokém školstvi. Praha: SLON.

Štech, S. (1994). Co je učitelství a lze se mu naučit? Pedagogika, 44(4), 310-320.

Štech, S. (2007). Profesionalita učitele v neo-liberální době: Esej o paradoxní situaci učitelství. Pedagogika, 57(4), 326-337.

Štech, S. (2014). Zpochybnění mýtů. In J. Dvořáčková, P. Pabian, S. Smith, T. Stöckelová \& K. Šima (Eds.), Politika a každodennost na českjch vysokých školách: etnografické pobledy na vzdèlávání a výzkum (s. 11-15). Praha: Sociologické nakladatelství.

Švec, V. (1996). Sebereflexe studentů v pregraduální didaktické přípravě. Pedagogika, 46(3), 266-276.

Švec, V. (2006). Pedagogická příprava učitelů v proměnách a nadějích. Pedagogika, 56(1), 1-4.

Švec, V., Lojdová, K., \& Pravdová, B. (Eds.). (2016). Učitelské praxe: Současné poznatky a perspektivy. Brno: Masarykova univerzita.

Švec, V., Svojanovský, P., \& Pravdová, B. (Eds.). (2016). Determinanty úcinnosti učitelských praxi. Brno: MuniPress.

Švecová, J., \& Vašutová, J. (1997). Problémy učitelského vzdělávání. In Problémy učitelské profese ve svètè (s. 116-117). Praha: Portál.

Tangney, S. (2014). Student-centerd learning: A humanist perspective. Teaching in Higher Education, 19(3), 266-275.

Trebulová, S. (2014). Spokojenost studentek nèmeckého jazyka s predmèty společného základu. (Bakalářská práce). Pedagogická fakulta Masarykovy univerzity.

Tůma, F., \& Knecht, P. (2019). Akademický inbreeding jako rakovina vysokého školství, nebo nezbytnost? Přehled zahraničních výzkumů a implikace pro českou vysokoškolskou politiku. Studia paedagogica, 24(1), 9-31.

Vašutová, J. (2002). Studentské portfolio. In J. Vašutová, Strategie výuky ve vysokoškolském vzdèlávání. Praha: Pedagogická fakulta UK.

Vašutová, J. (2004). Profese učitele v českém vzdélávacim kontextu. Brno: Paido.

Weltman, D., \& Whiteside, M. (2010). Comparing the effectiveness of traditional and active learning methods in business statistics. Convergence to the mean. Journal of Statistic Education, 18(1), 1-13. 
Wenger, E. (1999). Communities of practice: Learning, meaning, and indetity. New York: Cambridge University Press.

Windschitl, M. (2002). Framing constructivism in practice as the negotiation of dilemmas: An analysis of the conceptual, pedagogical, cultural, and political challenges facing teachers. Review of Educational Research, 72, 131-175.

Wright, A. W., Hamilton, B., Mighty, J., Scott, J., \& Muirhead, B. (2014). The Ontario Universities' Teaching Evaluation Toolkit: Feasibility study. Centre for Teaching and Learning Reports. Dostupné z http://scholar.uwindsor.ca/ctlreports/4

Younger, M., Brindley, S., Pedder, D., \& Hagger, H. (2004). Starting points: Student teachers' reasons for becoming teachers and their preconceptions of what this will mean. European Journal of Teacher Education, 27(3), 245-264.

doc. Mgr. Jana Kratochvilová, Ph.D.

Masarykova univerzita, Pedagogická fakulta, katedra pedagogiky;

e-mail: kratochvilova@ped.muni.cz

Mgr. Katerina Lojdová, Ph.D.

Masarykova univerzita, Pedagogická fakulta, katedra pedagogiky;

e-mail:lojdova@ped.muni.cz

KRATOCHVÍLOVÁ, J., LOJDOVÁ, K. Curriculum Reform of the Educational Psychology Module at the Faculty of Education, Masaryk University: The search for quality in the era of massification

The article traces the reform of the educational psychology module at the Faculty of Education, Masaryk University, which is a basic component of degree programmes for future teachers. It presents the starting-points, the progressively changing structural conditions and above all the dilemmas of the evolution of the module. On this basis it focuses on the principles of quality of university education and their evaluation. It sets the process of reform in the frame of university education in the era of massification. Last but not least, the text presents the personal reflection of the author, who has been participating in the reform of the curriculum of the educational psychological module.

Keywords: quality of teaching, pedagogical propaedeutics, curriculum reform, university teaching, teacher education, students of teaching. 


\section{Príloha}

Pedagogicko-psychologický modul na Pedagogické fakultě Masarykovy univerzity k 1. 9. 2016 Součástí společného základu dále je: tělesná výchova a cizí jazyk

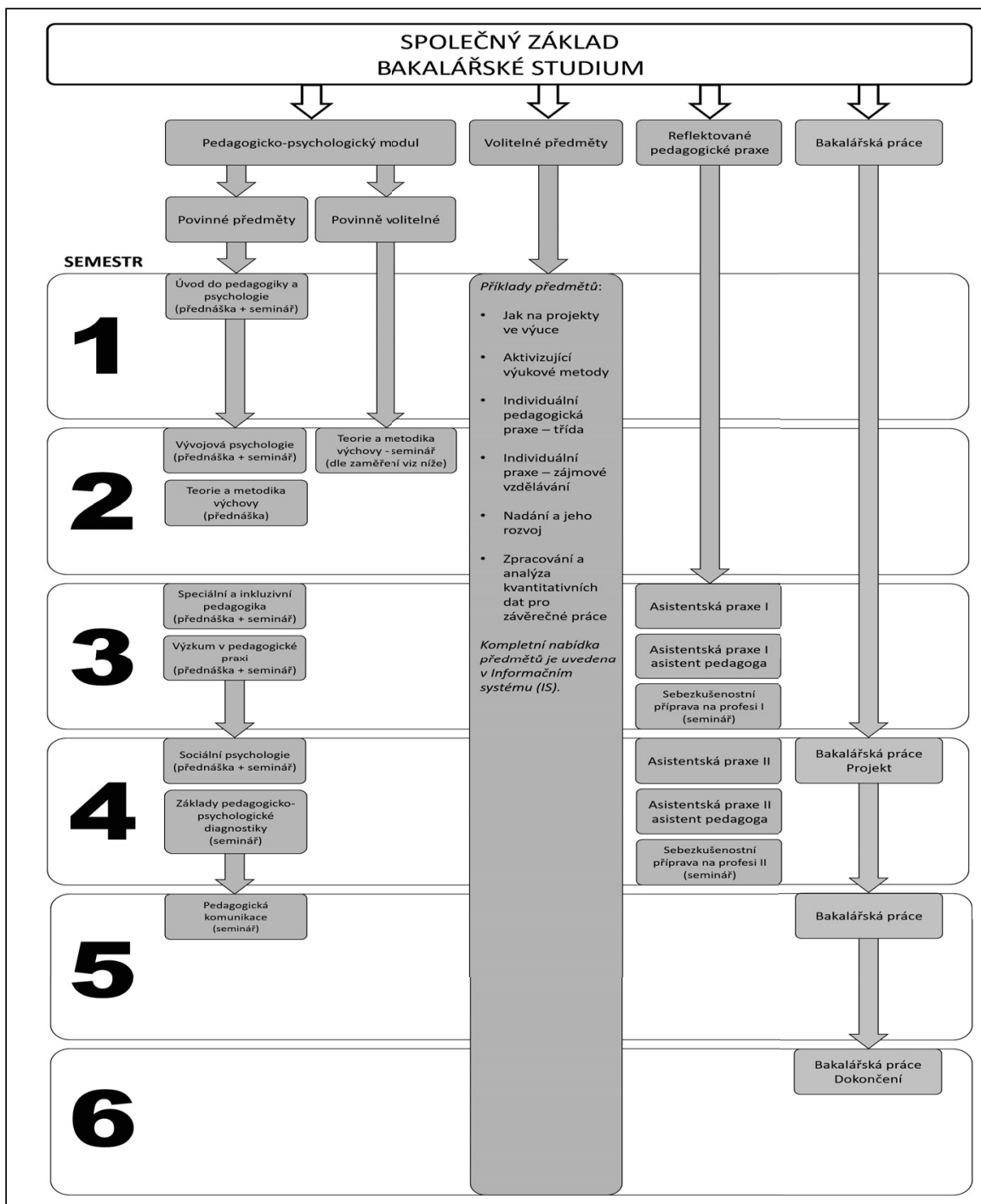




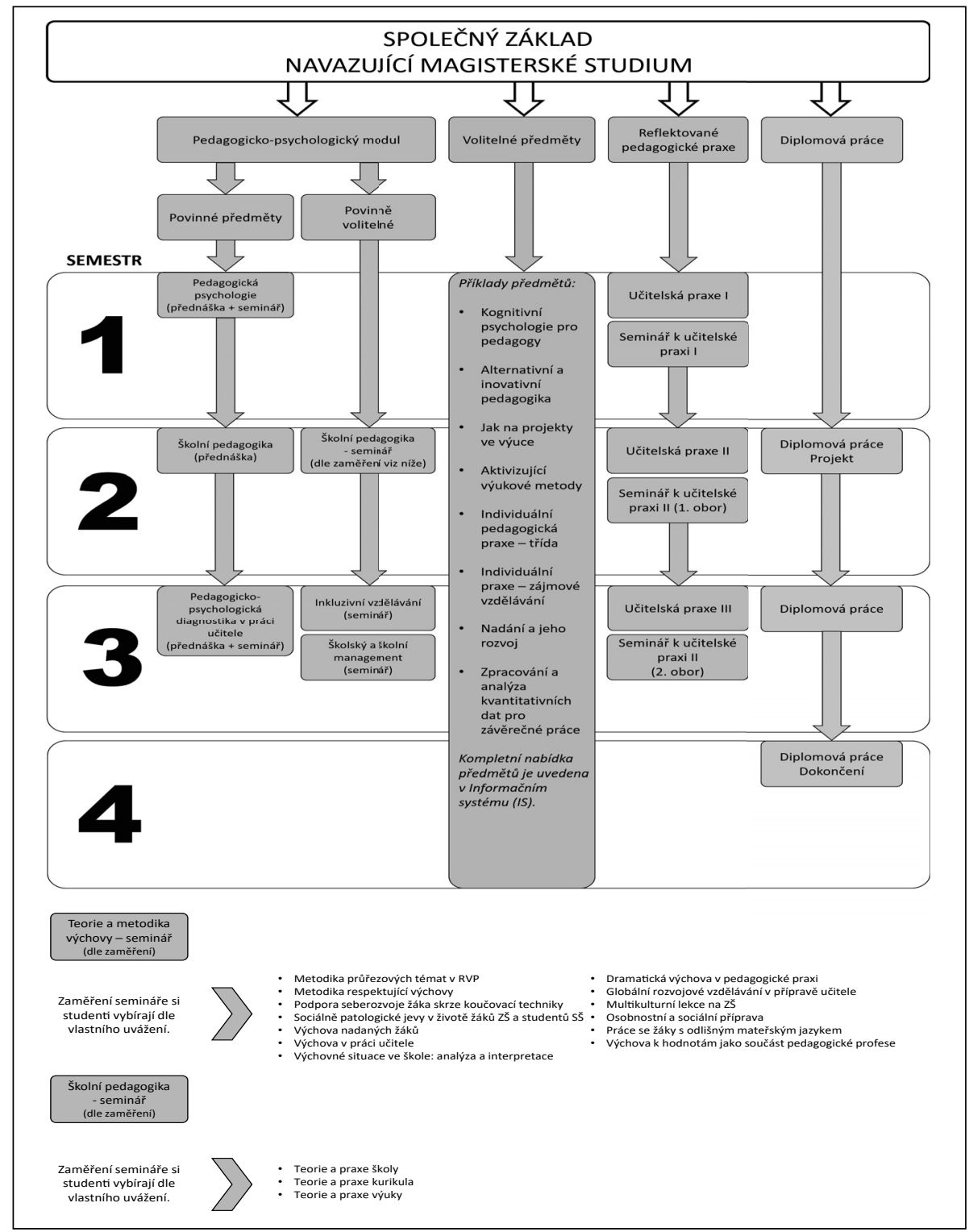

Více informací naleznete na http://katedry.ped.muni.cz/pedagogika 